\title{
FORMATION OF FUTURE KINDERGARTEN TEACHERS' ETHNOCULTURAL COMPETENCE IN NON-FORMAL ARTISTIC AND CREATIVE GROUPS
}

\author{
Nataliia Sulaieva \\ Poltava V.G. Korolenko National Pedagogical University, Ukraine \\ Olena Hnizdilova \\ Poltava V.G. Korolenko National Pedagogical University, Ukraine \\ Olha Palekha \\ Poltava V.G. Korolenko National Pedagogical University, Ukraine
}

\begin{abstract}
The purpose of the paper is to identify the role and place of non-formal artistic and creative groups in the process of formation of future kindergarten teachers' ethnocultural competence. Ethnocultural competence is considered by authors as an essential component of future kindergarten teachers' vocational training in condition of modern challenges, which Ukrainian society faces nowadays. The complex of theoretical and empirical research methods (literature analysis, interview, experiment, etc.) was used. The obtained results show positive dynamics of formation of future kindergarten teachers' ethnocultural competence after receiving non-formal education in artistic and creative groups at higher educational institution.
\end{abstract}

Keywords: artistic and creative groups, ethnical self-consciousness, ethnocultural competence, mentality, non-formal education.

\section{Introduction}

Nowadays, Ukraine is in a crucial time when it is important to protect the country's independence and sovereignty. It is efficient in this case to preserve and enhance the ethnocultural heritage of Ukrainians and to create conditions for its transmission to the young generation. A future kindergarten teacher has one of the leading positions in this process, developing the ethnic identity of a person, allowing him to receive knowledge and ideas about the culture, traditions, ideals, values of his people. This can be done based on the formation of the graduate's ethnocultural competence in higher education institutions.

Ukrainian scientists I. Beh (2003), P. Kononenko (2001), J. Rudenko (2001), N. Sulayeva (2017; 2018), P. Shherban', (2001), O. Visnevs'kij (2010) have developed and have approve ways and means of education of the young generation on the best spiritual and material models of Ukrainians. The scientists 
emphasize the importance of national education, which should be carried out continuously in different institutions such as families, preschool, general, extracurricular, vocational schools, children's and youth organizations and associations, territorial community. O. Dokukina (2008) has noted that national education should ensure a harmonious development of a personality, contribute to the flowering of his abilities and talents, and enrich the intellectual potential of the people, their spirituality and culture.

Introduction of ethnocultural component in the pedagogical process of educational institutions is analyzed by modern Ukrainian scientists A. Bohush and N. Lysenko (Bohush \& Lysenko, 2002). Specificity of formation of future kindergarten teachers' ethnocultural competence of students is considered by L. Kalashnyk, O. Novikov, K. Yur'yeva (Kalashnyk, Novikov, \& Yur'yeva, 2017). M. Olijnyk has analyzed the problem of ethnocultural self-consciousness of preschool children (Olijnyk, 2010). With all the undeniable importance of the theoretical and practical achievements of scholars on the future kindergarten teacher's training for national, ethnic education, it should be noted that sufficient material has not yet been accumulated to solve the problem of developing the ethnocultural competence of students of pedagogical universities in non-formal artistic and creative groups.

The purpose of our article is to determine the role and place of non-formal artistic and creative groups in the process of forming of future kindergarten teacher's ethnocultural competence.

To actualize the identified problem and to determine the effectiveness of enrichment of formal education (provided in higher educational institutions) with non-formal art one we used various methods: theoretical (content analysis of literature, terminological and comparative analysis to track the views of scientists and practitioners on the problem under study); empirical (diagnostic conversations, narrative interviews; observational (observation of artistic and educational activities of participants of artistic and creative groups during the experiment); pedagogical experiment.

\section{Literature review}

Using the term "ethnocultural competence of personality", we rely on the definition of domestic scientists O. Dokukina H. Lozko, O. Nel"ha, who considers it as the ability of a person to navigate freely in the world of the values of their ethnicity culture, to freely understand the language ("codes", "keys") of this ethnic culture and freely create in this language (Nel"ha, 1997, p. 289).

These researchers point out that the formation of the ethnocultural competence of the individual should begin in the family. It is believed that the vast majority of children relate themselves to the people to which his parents 
belong. Thus, O. Nel"ha states that if the members of the Ukrainian family can be recognized "because of their unique mentality" (Nel"ha, 1997, p. 136), ethnic morality, ethnic self-consciousness, and ethnic ideology, then naturally, the child brought up in that kind of family will consider himself Ukrainian.

We believe that it is essential for the development of the child's ethnical culture to gain an education in a preschool educational institution, where the defining factors are the skills, wisdom, views, beliefs, ideals, a spirituality of the kindergarten teacher, as well as his formed ethnocultural competence. Its development is a result of education in higher educational institutions

M. Yevtux states that the content-related component of future kindergarten teacher training in higher pedagogical educational institutions includes:

- future kindergarten teacher's professionally significant qualities and features of character;

- intelligence for the development of acumen, the professional orientation of perception, memory, thinking, imagination and enhancement of children's creative abilities;

- moral qualities, which include love for children, faith in their abilities and potential, pedagogical justice, respect for children and are the basis of professional ethics;

- $\quad$ spirituality, that is, the desire for truth in knowledge and work, beauty, which is the basis of the modern kindergarten teacher's general and pedagogical culture of the (Yevtux, 2008).

Subsequently, one of the influential factors in enriching the content of the future kindergarten teacher's vocational training with the national component and the formation of his ethnocultural competence is the creation of a sociocultural environment with distinct national characteristics in a higher educational institution

This environment allows integrating the formal component of education (future kindergarten teacher's theoretical and practical training) and the nonformal one (associations, groups, artistic and creative ones, in particular). The convergence of these educational activities makes the process of future kindergarten teacher's ethnocultural competence formation more effective. In Poltava V.G. Korolenko National Pedagogical University, students have an opportunity to strengthen their education with a non-formal component while studying various subjects such as "History of Ukraine", "Culture of Ukraine", "The Ukrainian Language", "Preschool Ethno Pedagogy and Methods of Acquaintance Children with Folk Studies", "Preschool Linguodidactics", etc. A non-formal component is represented by permanent artistic and creative groups, as well as, temporary ones created for participation in contests, competitions, presentations, projects, cultural-artistic events, etc. Taking part in 
these groups, future kindergarten teachers have an opportunity to obtain a nonformal art education. It is defined by N. Sulayeva as a person's voluntary artistic activity, which is carried out outside formal education in higher education institutions, and is mostly implemented in artistic and creative groups, and is not accompanied by the issuance of a state diploma (Sulayeva, 2018).

The individual-personal basis of the activities of non-formal artistic and creative groups' participants satisfies the needs of a particular person, using the potential of his free time. The content of this work is determined by the task to bring up high-spirited people who can protect, enrich and pass on to the future generations the national values of the Ukrainian people. That means to form their ethnocultural competence. This is especially effective if these artistic and creative groups have a national orientation. For example, there are more than 20 permanent non-formal artistic and creative groups of national orientation in Poltava V.G. Korolenko National Pedagogical University. Many of them are known in Ukraine and abroad. The following groups are, for instance, Ukrainian Folk Choir "Kalyna", Folk Amateur P. Lymanskii Choir, Folk Dance Group "Vesna”, Folk Ensemble "Zhyva Voda", Men's Ensemble "Chebrets" (Sulayeva, 2017). At the same time, temporary artistic and creative groups are systematically organized at the Faculty of Psychology and Pedagogy of Poltava V.G. Korolenko National Pedagogical University. Students have the opportunity to stage a folk tale, create a puppet theatre, organize a literary event, make a folk toy, etc.

A particular value of future kindergarten teachers' artistic activity in nonformal artistic and creative groups of national orientation is that they create favourable conditions for the development of their mentality, the formation of their ethnic morality, the deepening of ethnic self-consciousness, the enrichment of ethnocultural identity.

H. Lozko has noted that mentality is a national type of worldview ("spirit of the people"), which is based on ethnic images and symbols (often subconscious), which predetermine stereotypes of behaviour, mental reaction, evaluation of certain events or persons, attitude to the surrounding reality (Lozko, 2001, p. 291)

The main feature of the ethnic mentality of the Ukrainian people, according to the scholar O. Nel"ha, is the Ukrainian language, which is a form of the immortality of the ethnic group. Moreover, the concern about the future of the language is "obviously identical to the concern about the future of all Ukrainians, in general (Nel"ha, 1997, p. 136).

Participation in artistic and creative groups allows raising love and respect for the mother tongue. It helps to improve future kindergarten teachers' communicative competence as the basis of their ethnocultural competence. Students without any exceptions are allowed to take part in artistic and creative 
groups of national orientation. These can be students who do not speak Ukrainian at home, but Russian, Moldavian, Hungarian, etc. or speakers of ethnic dialects (the Lemko people, the Boyko people, the Hutsul people, etc.). Receiving non-formal art education in artistic and creative groups all students constantly speak literary Ukrainian, in particular, Kyiv-Poltava dialect.

At the same time, other mental traits of the Ukrainian people, which are important for the ethnocultural competence formation, are brought up in artistic and creative groups. O. Nel"ha defines then as the following:

- humanity, which includes peace, gentleness, charity sincerity, spirituality, cordiality, hospitality;

- democracy, which reflects the Cossack tradition of being elected to leadership positions, the equality of women with men in the family;

- peasantry (notable action ethnological trait);

- individualism, which is an invincible will, independence, autonomy, hostility diligence, desire for self-expression, perseverance, orientation, "stubbornness", optimism, confidence, cheerfulness, lyricism, song-loving) (Nel"ha, 1997, p. 147).

The formation of the above-mentioned features is based on the best samples of Ukrainian art. For example, in the process of performing folk dumas, songs, ballads, historical, lyric, children's songs future kindergarten teachers get acquainted with the best national musical samples. These are «Dobryj vechir tobi, pane hospodaryu», "Oj na hori ta j zhenci zhnut"», "Kozac"komu rodu nema perevodu», «Sydyt" Vasyl" na prypichyku», «Kotyku siren"kyj», etc. Folk songs are full of verbal symbols that overlap with the graphic, vegetable and animal symbols of the Ukrainian people, in particular: a viburnum, a willow, the star, a turtle-dove - a young lady; an oak, a maple, a falcon, the moon - a young man. Symbolic signs sung in songs are only a small part of the wealth of information that Ukrainian folk songs carry.

The future kindergarten teacher, who is a participant of the non-formal artistic vocal folk group, has an opportunity not only to develop his ethnocultural competence but also to deepen the knowledge about events and phenomena of social life, public and family way of living, work of Ukrainians by studying Ukrainian folk songs. There is information about the peculiarities of the struggle against the invaders, national and social oppression of the native people, and, most importantly, examples of the passionate love of the Ukrainian people for the Motherland.

The value of choreographic art in the development of the above-mentioned features is undeniable. For example, performing the folk dances «Zapletemo rohozu», «Hopak», «Kruzhalo», children's ones «Podolyanochka», «Kryvyj tanok», «Kody kozaky plachut"», "Vyjdy, vyjdy, sonechko» on stage future 
kindergarten teachers learn to respect the nature of the native land, reproduce the traditions of Ukrainians. They familiarize themselves with the labor skills of the Ukrainian people and deeply comprehend the specifics of folk beliefs

The formation of future kindergarten teachers' ethnocultural competence also occurs in non-formal theatrical groups, whose work is mainly aimed at developing communicative competence. As a rule, nationally-minded youth opt for works rich in folk songs, games, names of Ukrainian dishes: noodles, kulish, porridge (by I. Kotliarevskyi, I. Netchui-Levitskyi, I. Karpenko-Karyi), musical instruments: bandura, nostril, fipple flute (by I. Kotliarevskyi, T. Shevtchenko), elements of Ukrainian costume: skirt, corset, chain, boots, female headscarf, sheepskin coat (by I. Kotliarevskyi, I. Karpenko-Karyi, M. Starytskyi). It is valuable to form mental traits in the process of performing children's Ukrainian folk tales «Kolosok», «Pan Koc"kyj», «Lysychka sestrychka ta vovchyk-bratyk», «Koza-dereza», «Ivasyk Telesyk».

Performing and staging the fairy tales enables the participants of the national theatre to use the truly sacred sign of human communication - the word. Paying attention not only to the content of the text but also to the phonetic organization of speech - connectivity of sounds, alternation of vowels and consonants, intonation of lexical units, there is an increase in information (exchange of information), interactive (communication and influences of participants) and perceptual (perception by the senses) interrelation.

In the process of practical work in a non-formal theatre group, future kindergarten teachers improve the language skills of their mother tongue, master the experience of generations, knowledge of the surrounding reality to the extent that several times exceeds the experience of their peers. Therefore, it is impossible to overestimate the importance of participation of a student of a higher pedagogical institution in a theatre group.

Improvement of communicative competence and enrichment of vocabulary also occurs in the artistic and creative groups of decorative and applied art (embroidery, puppetry, Easter egg making, straw-works, etc.). Thus, working with items of folk use allows future kindergarten teachers to get acquainted with and learn: - the names of the elements of the Ukrainian costume in the process of making dolls (linen shirt, edge, corset, sheepskin coat, boots-marigolds, cap, capor, wreath, corals, ducats); - the names of the embroidery techniques that have long been common in Ukraine (undercutting, paving, cutting, mesh, carving, plumbing, cross, half-cross, suture stitch, embroidery on mesentery, loose surface, stitching, chain, pigtail, grating); - the terms related to the production of various clay products (potter, potter's wheel, mining, burning, polishing, smoking, snout, mug, plate, rattles, spice, weights, etc.).

At the same time, the formation of ethnocultural competence also occurs in the process of learning the symbolism of the Ukrainian people, which is 
extremely important for future kindergarten teachers. In non-formal artistic and creative groups, students have the opportunity to enrich their knowledge of the basic ornamental motives of Ukrainians, which have been developed for many centuries: • graphic symbols (point - beginning of all beginnings; points - stars; a line - the earth; dots between horizontal lines - sown field; a wave between two horizontal lines - land with water reserves; a square, a rhombus - symbols of earth fertility; a circle - the sun, symbol life, etc.); • the symbolic meaning of plants (a viburnum - the blood of the people, virgin beauty and virtue, love, the symbol of their native land; an oak - strength, courage, health; grapes - the joy of family happiness; periwinkle - longevity, enduring youth, declaration of love and family well-being; marigolds - male beauty; berries - welfare, harvest, etc.); - the significance of the images of birds (pigeons, turtles - love, honesty, sincerity, and faithfulness; a crane - the bird of the sun, the herald of fertility of the earth; a duck - a symbol of life, a swallow - goodness, happiness, revival, home comfort, a falcon - the sun, the sky, lightning, courageous young man, The First God, etc.).

A combination of formal education of future kindergarten teachers with non-formal art education in artistic and creative groups makes it possible to revise traditional spiritual values, norms, rules, requirements. It continues the formation of students' ethnic morality. We consider it one of the most important components of the ethnos' spiritual culture. H. Lozko states that it "inspires a person's life with a sense of inner mental radiation ... It, subconsciously instilling ethnic archetypes, ethnic images, and symbols, is a guide to where everyone's soul can immerse themselves in the warmth of the soul of the whole ethnic group" (Lozko, 2001, p. 289).

The providers of non-formal art education are aware of the close connection of ethnic morality with ethnic self-consciousness - a set of knowledge and ideas about the culture, traditions, ideals, values of their ethnicity, as well as the awareness of themselves as a member of the ethnic group, and the place of their ethnicity among other peoples. Therefore, activities in artistic and creative groups are directed to the development of ethnic selfconsciousness. It manifests itself in the future kindergarten teachers' ability to identify themselves with the Ukrainian ethnic group and to realize their ethnic "I" as a unique phenomenon. This is due to the future kindergarten teachers' professional activity. In Ukraine, there are occasions when a child is raised in a family, which is uncertain about attachment to one's ethnicity. Sometimes, even "zero" ethnical self-consciousness is formed.

It should be emphasized that artistic activity in artistic and creative groups contributes to the development of another component of self-consciousness - the feeling of the Motherland. Its formation is caused by the action of many factors. In particular, O. Nel"ha distinguishes such factors as the land of ancestors, 
country of birth and growth (ethnicization) - "the country of childhood", place of birth and growth, state of rooted residence, locality of rooted residence, etc." (Nel"ha, 1997, p. 104).

\section{Research results}

Based on the foregoing, the practicability of a convergent combination of future kindergarten teachers' formal education of non-formal art education in artistic and creative groups in Poltava V.G. Korolenko National Pedagogical University requires experimental verification.

Firstly, we determined the proportion of a cultural and artistic component in the system of formal and non-formal education of students of specialty "Preschool education". An analysis of educational programs and curriculum showed that national cultural and artistic component makes up $27.9 \%$ of the total ECTS credits. The proportion of the cultural and artistic component in the non-formal education of future kindergarten teachers in Poltava V.G. Korolenko National Pedagogical University showed almost 65\%.

The next stage was the interviewing of 49 third-year students of the specialty "Preschool Education", which allowed determining the number of students who received and who did not receive non-formal art education in the artistic and creative groups in Poltava V.G. Korolenko National Pedagogical University. Interview results showed that $10.2 \%$ (5 students) participated in permanent artistic and creative groups and $73.5 \%$ (36 students) - in temporary ones. Thus, interviewing showed that more than a quarter of the students $26.5 \%$ (13 students) did not take part in artistic and creative groups and received only formal education in Poltava V.G. Korolenko National Pedagogical University.

An important question for us was to determine whether the combination of formal and non-formal education of future kindergarten teachers influences the formation of their ethnocultural competence or does not affect this process.

In this regard, we created two groups of students of 13 people. The first group consisted of students who did not receive non-formal education in an artistic and creative group, and the Second group - students who received formal and non-formal education. To create the same conditions, we analyzed the results of formal education -academic results of the First group students (students who did not combine formal education with non-formal education). It turned out that out of 13 future kindergarten teachers, 23.1\% (3 students) got high academic results - A level, 46.1\% (6 students) got good academic results (B level) and 30.8\% (4 students) had satisfactory academic results - level C.

Among students who combined formal education with non-formal one, we identified the Second group. It included students who had the same academic 
results as the First group (Level A - 3 students, Level B - 6 students, Level C 4 students).

To diagnose the ethnocultural competence formation of students of the First and Second groups, we defined the criteria and indicators of these criteria.

The definition of the criteria was correlated with the awareness of the concept of ethnocultural competence. Its important component is a free orientation in the world of the values of the culture of one's ethnic group. Accordingly, the first criterion was defined as the criterion of cultural and artistic development. Its indicators were: future kindergarten teachers' motivation to cultural, artistic and educational activities; knowledge of folk artworks; fluent in Ukrainian.

The second criterion according to the components of ethnocultural competence was the criterion of social development. It correlates with the free understanding of non-verbal "codes" "keys" of Ukrainian ethnocultural and fluent use of these non-verbal means. Indicators of this criterion were: the focus on designing strategies for one's life following social norms and rules defined in Ukrainian society; daily behaviour following the traditions and preferences of the Ukrainian people; social national competence of a personality)

Taking into consideration that all components of ethnocultural competence are important components of the spiritual development of the individual, we have chosen another criterion - spiritual development. We chose the following indicators: spiritual potential in the structure of personality; the importance of spiritual national values in the general system of personality values; effectiveness of pedagogical communication in the context of national education.

To determine the criteria for the future kindergarten teachers' development in artistic and creative groups, quantitative characteristics of qualitative indicators were established. The data was acquired to be a means of using diagnostic psychological and pedagogical tools. In particular, a three-point system of complex evaluation of each indicator was used: 3 points - high level, 2 points - sufficient level, 1 point - elementary levels.

To assess ethnocultural competence development according to the criteria of cultural and artistic, and social development students of the First and the Second groups participated in testing, questioning and interviewing were used. These research methods showed that, by the criterion of cultural and artistic development, the results of the First group were significantly outweighed by the high and sufficient levels of the respondents in the Second group (the quantitative and qualitative indicators are presented in Table 1). At the same time, indicators for the criterion of social development outweighed the benefit of the Second Group by a much smaller percentage (Table 1). Assessment of ethnocultural competence development according to the criteria of spiritual 
development was performed based on integrative test methods by Ukrainian psychologist E. Pomitkin (spiritual potential of the personality, the method of revealing the formation of spiritual value orientation of the individual) (Pomitkin, 2013) and a modified questionnaire of pedagogical communications effectiveness. The results by the last criterion also showed the merit of development levels in favour of the Second Group (Table 1).

\section{Table 1 Assessment of the formation of future kindergarten teachers' ethnocultural conpetence}

\begin{tabular}{|c|c|c|c|c|c|c|c|c|c|c|c|c|c|c|c|c|c|c|}
\hline Criterion & \multicolumn{18}{|c|}{ Cultural and artistic development } \\
\hline Indicator & \multicolumn{6}{|c|}{ The first indicator } & \multicolumn{6}{|c|}{ The second indicator } & \multicolumn{6}{|c|}{ The third indicator } \\
\hline Level & \multicolumn{2}{|c|}{ High } & \multicolumn{2}{|c|}{ Sufficient } & \multicolumn{2}{|c|}{ Elem } & \multicolumn{2}{|c|}{ High } & \multicolumn{2}{|c|}{ Sufficient } & \multicolumn{2}{|c|}{ Elem } & \multicolumn{2}{|c|}{ High } & \multicolumn{2}{|c|}{ Sufficient } & \multicolumn{2}{|c|}{ Elem } \\
\hline Amount & $\mathrm{A}$ & $\%$ & A & $\%$ & $\mathrm{~A}$ & $\%$ & A & $\%$ & $\mathrm{~A}$ & $\%$ & $\mathrm{~A}$ & $\%$ & A & $\%$ & $\mathrm{~A}$ & $\%$ & $\mathrm{~A}$ & $\%$ \\
\hline $\begin{array}{l}\text { The First } \\
\text { group }\end{array}$ & 2 & 15,4 & 9 & 69,2 & 2 & 15,4 & 3 & 23,1 & 7 & 53,8 & 3 & 23.1 & 5 & 38,5 & 7 & 53,8 & 1 & 7,7 \\
\hline $\begin{array}{l}\text { The } \\
\text { Second } \\
\text { group }\end{array}$ & 6 & 46,2 & 7 & 53,8 & 0 & 0 & 9 & 69,2 & 4 & 30,8 & 0 & 0 & 6 & 46,1 & 6 & 46,2 & 1 & 7,7 \\
\hline Criterion & \multicolumn{18}{|c|}{ Social Development } \\
\hline Indicator & \multicolumn{6}{|c|}{ The first indicator } & \multicolumn{6}{|c|}{ The second indicator } & \multicolumn{6}{|c|}{ The third indicator } \\
\hline Level & \multicolumn{2}{|c|}{ High } & \multicolumn{2}{|c|}{ Sufficient } & \multicolumn{2}{|c|}{ Elem } & \multicolumn{2}{|c|}{ High } & \multicolumn{2}{|c|}{ Sufficient } & \multicolumn{2}{|c|}{ Elem } & \multicolumn{2}{|c|}{ High } & \multicolumn{2}{|c|}{ Sufficient } & \multicolumn{2}{|c|}{ Elem } \\
\hline Amount & $\mathrm{A}$ & $\%$ & A & $\%$ & $\mathrm{~A}$ & $\%$ & $\mathrm{~A}$ & $\%$ & $\mathrm{~A}$ & $\%$ & $\mathrm{~A}$ & $\%$ & A & $\%$ & $\mathrm{~A}$ & $\%$ & $\mathrm{~A}$ & $\%$ \\
\hline $\begin{array}{l}\text { The First } \\
\text { group }\end{array}$ & 4 & 30,8 & 8 & 61,5 & 1 & 7,7 & 4 & 30,8 & 7 & 53,8 & 2 & 54,4 & 5 & 38,5 & 7 & 53,8 & 1 & 7,7 \\
\hline $\begin{array}{l}\text { The } \\
\text { Second } \\
\text { group }\end{array}$ & 6 & 46,1 & 6 & 46,2 & 1 & 7,7 & 6 & 46,1 & 6 & 46,2 & 1 & 7,7 & 8 & 61,5 & 5 & 38,5 & 0 & 0 \\
\hline Criterion & \multicolumn{18}{|c|}{ Spiritual development } \\
\hline Indicator & \multicolumn{6}{|c|}{ The first indicator } & \multicolumn{6}{|c|}{ The second indicator } & \multicolumn{6}{|c|}{ The third indicator } \\
\hline Level & \multicolumn{2}{|c|}{ High } & Suf & ficient & & lem & & Tigh & Suff & ficient & & lem & & igh & Suff & ficient & & lem \\
\hline Amount & $A$ & $\%$ & A & $\%$ & A & $\%$ & A & $\%$ & A & $\%$ & $A$ & $\%$ & $\mathrm{~A}$ & $\%$ & $\mathrm{~A}$ & $\%$ & $\mathrm{~A}$ & $\%$ \\
\hline \begin{tabular}{|l|} 
The First \\
group
\end{tabular} & 4 & 30,8 & 9 & 69,2 & 0 & 0 & 4 & 30,8 & 4 & 30,8 & 5 & 38,4 & 5 & 38,5 & 6 & 36,1 & 2 & 15,4 \\
\hline \begin{tabular}{|l} 
The \\
Second \\
group
\end{tabular} & 5 & 38,5 & 8 & 61,5 & 0 & 0 & 5 & 38,5 & 8 & 61,5 & 0 & 0 & 9 & 69,2 & 4 & 30,8 & 0 & 0 \\
\hline
\end{tabular}

$A$ - amount of students.

For the visual perception of the results of the experimental study, it is necessary, in our opinion, to represent them in the form of a diagram (Figure 1). 


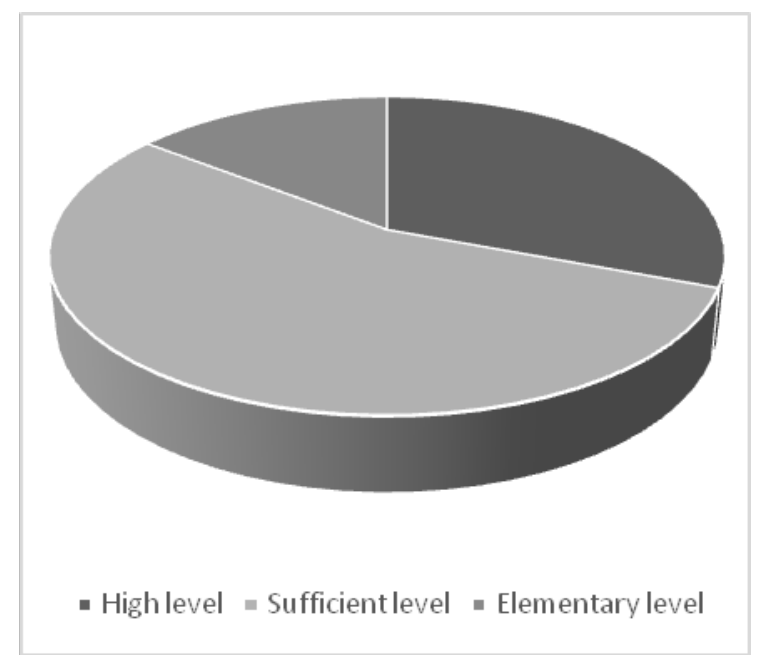

The First group

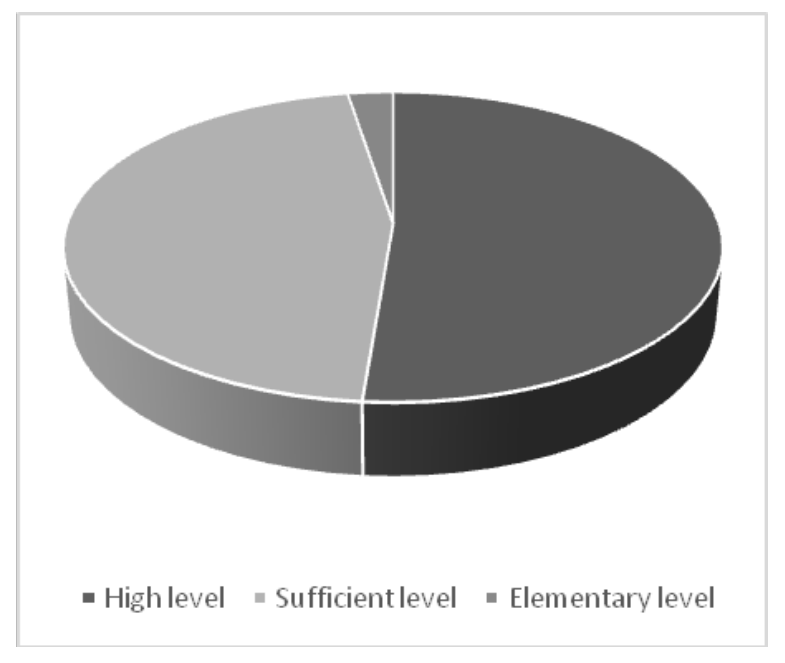

The Second group

Figure 1 Levels of formation of future kindergarten teachers' ethnocultural conpetence

\section{Conclusions}

Based on the foregoing, we can conclude that the nature of future kindergarten teachers' ethnocultural competence artistic and creative groups. An important component of future kindergarten teachers' vocational training is the formation of a specialist, who has a high level of ethnocultural competence formation.

One of the factors that can positively influence the formation of future kindergarten teachers' ethnocultural competence is a convergence of formal and non-formal education in higher education institutions, in particular in the artistic and creative groups of national orientation. The benefit of this convergence is the enrichment of the formal education components.

Thus, an example of an institution of higher pedagogical education that combines formal education with non-formal art one in artistic and creative groups is Poltava V.G. Korolenko National Pedagogical University.

In the process of artistic and educational activity in groups, future kindergarten teachers receive non-formal education by mastering the best examples of the musical, choreographic, visual, and literary art of the Ukrainian people. Therefore, favourable conditions are created for the development of the future specialists' mentality, formation of their ethnic morality, deepening of the ethnical self-consciousness, and formation of the ethnocultural competence The necessity to converge formal education with non-formal art one in artistic and creative groups to form ethnocultural competences is proved by the results of the experiment. The experiment showed that the levels of ethnocultural competence in all the defined indicators (cultural and artistic, social and spiritual development) of future kindergarten teachers, who combined formal education 
with non-formal one in artistic and creative groups, greatly outweigh those students who did not.

Concerning the experimental study results, we can assert that future kindergarten teachers, who has enriched formal education with non-formal art education and therefore has a well-formed Ukrainian mentality, ethnic morality, and ethical self-consciousness can become a carrier of the ethnocultural heritage of the Ukrainian people. In this regard, a feeling of originality, uniqueness, and beauty of ethnic achievements will allow creating an environment for new creative pursuits, discoveries, unique methods of self-expression of future kindergarten teachers and the young generation of our state, as well.

\section{References}

Beh, I.D. (2003). Vihovannja osobistosti. Osobistisno orientovanij pidhid: naukovopraktichni zasadi. Kyiv: Libid'.

Bohush, A.M., \& Lysenko, N.V. (2002). Ukrayins"ke narodoznavstvo v doshkil"nomu zakladi. Kyiv: Vyshha shkola.

Dokukina, O. (2008). Nacional"ne vyxovannya ditej i uchnivs"koyi molodi. In V. Kremin (Ed.), Encyklopediya osvity (pp. - 569). Kyiv: Xrinkom Inter.

Kalashnyk, L.S., Novikov, O.V., \& Yur'yeva, K.A. (2017). Interaktyvni formy roboty v pidhotovci majbutnix uchyteliv i vyxovateliv do profesijnoyi diyal"nosti $\mathrm{v}$ umovax etnokul"turnoho riznomanittya suchasnoho suspil"stva. Zasoby navchal"noyi ta naukovo-doslidnoyi roboty, 48, 77-93.

Kononenko, P.P. (2001). Osvita XXI stolittja: Filosofija rodinnosti. Kyiv: Artek.

Lozko, H.S. (2001). Etnolohiya Ukrayiny. Filosofs"ko-teoretychnyj ta etnorelihiyeznavchyj aspekt. Kyiv: ArtEk.

Nel"ha, O.V. (1997). Teoriya etnosu. Kyiv: TANDEM.

Olijnyk, M.I. (2010). Polikul"turne vyxovannya yak proces formuvannya etnichnoyi identychnosti ta tolerantnosti u ditej doshkil"noho viku. Visnyk Prykarpats"koho universytetu: Pedahohika. XXXVI, 35-39.

Pomitkin, E.O. (2013). Psihologichna diagnostika duhovnogo potencialu osobistosti. Kirovograd: Imeks-LTD.

Rudenko, Ju. (2001). Ukraïns'ka narodna kazka v rodinnomu vihovanni ditej. Visnik Prikarpats'kogo universitetu. Pedagogika, 6, 110-114.

Shherban', P. (2001). Nacional'nij doktrini - nacional'nij zmist. Ridna shkola, 5, 11-12.

Sulayeva, N.V. (2017). Aksiolohichni oriyentyry neformal"noyi mystec"koyi osvity majbutnix uchyteliv. Mystectvo ta osvita 2017, 4(86), 2-6.

Sulayeva, N.V. (2018). Konverhentnist" riznyx vydiv mystec"koyi osvity studentiv psyxoloho-pedahohichnoho fakul"tetu Poltavs"koho nacional"noho pedahohichnoho universytetu imeni V. H. Korolenka. Estetyka i etyka pedahohichnoyi diyi, 17, 119-128.

Vishnevs'kij, O. (2010). Ukraïns'kij vihovnij ideal i nacional'nij harakter (vitoki, deformaciï $i$ suchasni vikliki). Drogobich: Vidavec' Svjatoslav Surma.

Yevtux, M. (2008). Orhanizaciya navchal"no-vyxovnoho procesu u pedahohichnyx navchal"nyx zakladax. In V. Kremin (Ed.), Encyklopediya osvity (pp. 614 - 617). Kyiv: Xrinkom Inter. 